\title{
RESPON PERTUMBUHAN BIBIT KAKAO (Theobroma cacao, L) PADA TANAH MARGINAL YANG DIBERIKAN MIKORIZA
}

\author{
Mutia Erdayana ${ }^{1}$ Syukri $^{2}$,Iswahyudi ${ }^{{ }^{2}}$ \\ ${ }^{1}$ Mahasiswa Program Studi Agroteknologi Fakultas Pertanian Universitas Samudra. ${ }^{2}$ Dosen Program \\ Studi Agroteknologi Fakultas Pertanian Universitas Samudra \\ "Email: iswahyudi@unsam.ac.id
}

\begin{abstract}
ABSTRAK
Penelitian ini bertujuan untuk mengetahui respon pertumbuhan bibit kakao (Theobroma cacao, L) pada tanah marginal yang diberikan mikoriza, serta interaksi kedua perlakuan tersebut. Penelitian ini menggunakan Rancang Acak Kelompok (RAK) pola fakorial yang terdiri dari 2 faktor, yaitu: faktor jenis tanah marginal dengan notasi $(\mathrm{T})$ yang terdiri dari 4 taraf yaitu: $\mathrm{T}_{1} \quad=$ Tanah top soil (kontrol), $\mathrm{T}_{2}=$ Tanah bekas tambang, $\mathrm{T}_{3}=$ Tanah yang ditumbuhi tanaman alang-alang, $\mathrm{T}_{4}=$ Tanah bekas terbakar. Faktor dosis mikoriza dengan notasi (M) yang terdiri dari 4 taraf yaitu : $\mathbf{M}_{0}=0$ $\mathrm{g} /$ polybag (kontrol), $\mathrm{M}_{1}=5 \mathrm{~g} /$ polybag, $\mathrm{M}_{2}=10 \mathrm{~g} /$ polybag, $\mathrm{M}_{3}=15 \mathrm{~g} /$ polybag. Parameter yang diamati antara lain: tinggi bibit, diameter pangkal batang, jumlah daun, panjang daun, bobot brangkasan basah bibit dan bobot basah akar.Hasilpenelitian menunjukkan bibit kakao akibat perlakuan jenis tanah marginal menunjukkan respon yang sangat nyata terhadap tinggi bibit umur (50 dan 65 HST), jumlah daun umur 65 HST, panjang daun umur (50 dan 65 HST), bobot brangkasan basah bibit, bobot basah akar, respon nyata terhadap tinggi bibit umur (20 dan 35 HST), jumlah daun umur (35 dan 50 HST) dan panjang daun umur 35 HST. Pertumbuhan bibit kakao akibat perlakuan dosis mikoriza menunjukkan respon yang sangat nyata terhadap tinggi bibit umur (35, 50 dan $65 \mathrm{HST})$, jumlah daun umur ( 35 dan 65 HST), panjang daun umur (35, 50 dan 65 HST), bobot brangkasan basah bibit, bobot basah akar, respon nyata terhadap jumlah daun umur 50 HST. Interaksi antara jenis tanah marginal dan dosis mikoriza memberikan respon yang nyata terhadap parameter jumlah daun bibit kakao umur 35 HST. Kombinasi perlakuan terbaik yaitu jenis tanah marginal tanah top soil dan dosis mikoriza 15 $\mathrm{g} /$ polybag $\left(\mathrm{T}_{1} \mathrm{M}_{3}\right)$ yang dilakukan secara bersamaan.
\end{abstract}

Kata kunci :Tanah Marginal, Mikoriza, Bibit Kakao.

\section{PENDAHULUAN}

Kakao (Theobroma cacao, L) merupakan salah satu komuditas andalan nasional dan berperan penting bagi perekonomian Indonesia, terutama dalam penyediaan lapangan kerja, sumber pendapatan petani, dan sumber devisa bagi negara (Lukito $d k k$., 2010). Produksi kakao Indonesia pada tahun 2015 yaitu 593.331 ton, selanjutnya pada tahun 2016 meningkat menjadi 656.817 ton (BPS Indonesia, 2017). Salah satu aspek budidaya kakao yang penting diperhatikan adalah tahap pembibitan. Kendala yang dihadapi dalam pembibitan skala besar adalah keterbatasan tanah-tanah yang subur, gembur dan kaya bahan organik. Untuk mengatasi permasalahan ini perlu dilakukan pengujian pada tanah marginal yang masih banyak tersedia seperti tanah bekas tambang, tanah yang ditumbuhi alang-alang, dan tanah bekas terbakar. Menurut Yuwono, (2009) tanah marginal merupakan tanah yang memiliki mutu rendah karena mempunyai beberapa faktor pembatas, diantaranya: ketersediaan hara rendah, keasaman lebih tinggi, kandungan bahan organik rendah, tingkat erosivitas tinggi, dan jika keasaman terlalu rendah mempunyai tingkat keracunan tinggi. Keadaan tanah yang demikian akan menyebabkan pertumbuhan tanaman tidak optimal, sehingga diperlukan perlakuan-perlakuan khusus agar tanaman dapat tumbuh dengan baik dan adaptif terhadap kondisi lapangan. 
Peningkatan kesuburan tanah marginal dan pertumbuhan tanaman kakao dapat dilakukan dengan memanfaatkan cendawan mikoriza. Potensi biologis mikoriza dan prospek aplikasinya telah diketahui secara luas, diantaranya dapat memacu pertumbuhan tanaman, menyediakan unsur hara bagi tanaman, membuat tanaman mampu beradaptasi dengan lingkungan yang kurang baik serta secara tidak langsung dapat memberikan manfaat berupa peningkatan kesuburannya menjadi lebih baik. Jamur Mikoriza sejenis jamur yang bersimbiosis dengan akar Mikoriza Arbuskula yang bersimbiosis dengan akar tanaman, mampu meningkatkan serapan unsur hara $\mathrm{N}, \mathrm{P}$ dan, $\mathrm{K}$ dan meningkatkan efisiensi penggunaan air tanah, meningkatkan nilai tegangan osmotik sel-sel tanaman pada tanah yang kadar airnya cukup rendah, sehingga tanaman dapat melangsungkan kehidupannya serta mampu meningkatkan laju pertumbuhan vegetatif dan produksi tanaman (Nasaruddin, 2012).

Mikoriza dapat meningkatkan nilai tegangan osmotik sel-sel tanaman pada tanah yang kadar airnya cukup rendah, sehingga tanaman dapat melangsungkan kehidupannya serta mampu meningkatkan laju pertumbuhan vegetatif dan produksi tanaman (Idhan dan Nursjamsi, 2016). Hasil penelitian Nasrullah $d k k$., (2015) aplikasi mikoriza dapat mempengaruhi pertumbuhan bibit kakao, dimana perlakuan dosis mikoriza berpengaruh sangat nyata terhadap luas daun dan persentase akar terinfeksi mikoriza, berpengaruh nyata terhadap tinggi bibit dan diameter pangkal batang, berat basah akar dan berat kering berangkasan atas. Pertumbuhan bibit kakao pada media tumbuh sub soil lebih efektif dijumpai pada dosis mikoriza $10 \mathrm{~g} /$ tanaman.

\section{METODE PENELITIAN}

Penelitian ini telah dilaksanakan di Desa Keude Dua Kecamatan Darul Ihsan Kabupaten Aceh Timur dengan ketinggian tempat 15 meter di atas permukaan laut (dpl) (memakai aplikasi Altitude). Waktu penelitian dilakukanselama 4 (empat) bulan, yaitu dari bulan Desember 2018 sampai Maret 2019. Alat-alat yang digunakan dalam penelitian ini antara lain : cangkul, parang, pisau, palu, gergaji, meteran, timbangan analitik, timbangan manual,handsprayer, gembor, ayakan, jangka sorong, ayakan tanah (kawat besi), alat tulis menulis, kamera. Adapun bahan-bahan yang digunakan dalam penelitian ini antara lain : bibit kakao klon Sulawesi 2 yang diperoleh dari Koperasi Perkebunan Kakao Bireun (KOPBUN), tanah top soil ordo Ultisol yang diambil dari Desa Keude Dua Kecamatan Darul Ihsan Kabupaten Aceh Timur, tanah marginal (tanah bekas tambang yang didapatkan dari Desa Benteng Kecamatan Ranto Peureulak Kabupaten Aceh Timur, tanah yang ditumbuhi alang-alang dan tanah bekas terbakar didapatkan dari Desa Lhouk Leumak Kecamatan Darul Ihsan Kabupaten Aceh Timur), cendawan mikoriza arbuskula spesies Glomus sp yang didapatkan dari kampus Universitas Syiah Kuala Banda Aceh,pupuk Urea, pupuk TSP, pupuk KCl, Insektisida Sevin 500 EC, Fungisida Dithane M-45, polybag ukuran $18 \times 25 \mathrm{~cm}$ dengan volume $2 \mathrm{~kg}$, bambu, paranet, air, paku, cat dan triplek.

Penelitian ini menggunakan Rancang Acak Kelompok (RAK) pola fakorial yang terdiri dari 2 faktor, yaitu: faktor jenis tanah marginal dengan notasi $(\mathrm{T})$ yang terdiri dari 4 taraf yaitu: $\mathrm{T}_{1}=$ Tanah top soil (kontrol), $\mathrm{T}_{2}=$ Tanah bekas tambang, $\mathrm{T}_{3}=$ Tanah yang ditumbuhi tanaman alang-alang, $\mathrm{T}_{4}=$ Tanah bekas terbakar. Faktor dosis mikoriza dengan notasi (M) yang terdiri dari 4 taraf yaitu : $\mathrm{M}_{0}=0 \mathrm{~g} /$ polybag (kontrol), $\mathrm{M}_{1}=5 \mathrm{~g} /$ polybag, $\mathrm{M}_{2}=10 \mathrm{~g} /$ polybag, $\mathrm{M}_{3}=15 \mathrm{~g} /$ polybag. Parameter yang diamati antara lain: tinggi bibit, diameter pangkal batang, jumlah daun, panjang daun, bobot brangkasan basah bibit dan bobot basah akar. 


\section{HASIL DAN PEMBAHASAN}

\section{Respon Pertumbuhan Bibit Kakao akibat Jenis Tanah Marginal}

\section{Tinggi Bibit (cm)}

Rata-rata tinggi bibit kakao pada umur 20, 35, 50 dan 65 HST akibat perlakuan jenis tanah marginal disajikan pada Tabel 1.

Tabel 1. Rata-rata Tinggi Bibit Kakao akibat Perlakuan Jenis Tanah Marginal

\begin{tabular}{ccccc}
\hline \multirow{2}{*}{ Perlakuan } & \multicolumn{4}{c}{ Tinggi Bibit $(\mathrm{cm})$} \\
\cline { 2 - 5 } & $20 \mathrm{HST}$ & $35 \mathrm{HST}$ & $50 \mathrm{HST}$ & 65 HST \\
\hline $\mathrm{T}_{1}$ & $11,67 \mathrm{~b}$ & $15,27 \mathrm{~b}$ & $20,17 \mathrm{~b}$ & $28,13 \mathrm{~b}$ \\
$\mathrm{~T}_{2}$ & $10,42 \mathrm{ab}$ & $13,88 \mathrm{a}$ & $17,83 \mathrm{a}$ & $24,81 \mathrm{a}$ \\
$\mathrm{T}_{3}$ & $10,33 \mathrm{a}$ & $13,94 \mathrm{a}$ & $17,71 \mathrm{a}$ & $25,04 \mathrm{a}$ \\
$\mathrm{T}_{4}$ & $10,67 \mathrm{ab}$ & $14,21 \mathrm{ab}$ & $17,73 \mathrm{a}$ & $25,15 \mathrm{a}$ \\
\hline BNJ $_{0,05}$ & 1,30 & 1,26 & 1,76 & 2,25 \\
\hline
\end{tabular}

Keterangan: Angka yang diikuti oleh huruf yang sama pada kolom yang sama berbeda tidak nyata pada uji $\mathrm{BNJ}_{0,05}$

Tabel 1 menunjukkan bahwa tinggi bibit kakao umur 20, 35, 50 dan 65 HST tertinggi dijumpai pada perlakuan $\mathrm{T}_{1}$ (tanah top soil). Pada umur 20 dan 35 HST perlakuan $\mathrm{T}_{1}$ secara uji $\mathrm{BNJ}_{0,05}$ berbeda nyata dengan perlakuan $\mathrm{T}_{2}$ (tanah bekas tambang) dan $\mathrm{T}_{3}$ (tanah yang ditumbuhi alang-alang), namun berbeda tidak nyata dengan perlakuan $\mathrm{T}_{4}$ (tanah bekas terbakar). Pada umur 50 dan 65 HST perlakuan $T_{1}$ secara uji $\mathrm{BNJ}_{0,05}$ berbeda nyata dengan perlakuan $\mathrm{T}_{2}, \mathrm{~T}_{3}$ dan $\mathrm{T}_{4}$.

Hal ini disebabkan tanah top soil memiliki tingkat kesuburan yang lebih baik dibandingkan tanah marginal, dimana kandungan bahan organik dan unsur hara yang terkandung dalam tanah top soil lebih tinggi sehingga dapat meningkatkan pertumbuhan tinggi bibit kakao. Hal tersebut sesuai dengan pendapat Nyakpa $d k k$., (2002) yang menyatakan bahwa tanah top soil mengandung bahan organik yang merupakan bahan penting dalam menciptakan kesuburan tanah, baik secara fisika, kimia maupun dari segi biologi tanah. Bahan organik merupakan sumber hara tanaman dan sumber energi dari sebagian besar organisme tanah, sehingga dapat meningkatkan pertumbuhan tanaman.

\section{Diameter Pangkal Batang (mm)}

Rata-rata diameter pangkal batang bibit kakao pada umur 20, 35, 50 dan 65 HST akibat perlakuan jenis tanah marginal disajikan pada Tabel 2.

Tabel 2. Rata-rata Diameter Pangkal Batang Bibit Kakao akibat Perlakuan Jenis Tanah Marginal

\begin{tabular}{ccccc}
\hline \multirow{2}{*}{ Perlakuan } & \multicolumn{4}{c}{ Diameter Pangkal Batang $(\mathrm{mm})$} \\
\cline { 2 - 5 } & $20 \mathrm{HST}$ & 35 HST & $50 \mathrm{HST}$ & 65 HST \\
\hline $\mathrm{T}_{1}$ & 3,01 & 4,39 & 5,56 & 7,60 \\
$\mathrm{~T}_{2}$ & 2,72 & 4,00 & 5,11 & 7,13 \\
$\mathrm{~T}_{3}$ & 2,93 & 4,06 & 5,10 & 7,07 \\
$\mathrm{~T}_{4}$ & 2,91 & 4,07 & 5,41 & 7,30 \\
\hline
\end{tabular}

Tabel 2 menunjukkan bahwa pertumbuhan bibit kakao akibat perlakuan jenis tanah marginal menunjukkan respon yang tidak nyata padadiameter pangkal batang umur 20, 35, 50 dan 65 HST.Hal tersebut diduga pertumbuhan diameter pangkal batang bibit kakao dipengaruhi oleh sifat genetis, sehingga perlakuan yang diuji tidak memberikan pengaruh yang nyata. Hal tersebut sesuai dengan pendapat Sitompul dan Guritno (1995) bahwa penampilan tanaman dikendalikan oleh sifat genetik di bawah pengaruh faktor-faktor lingkungan. Kendali genetik pada penampilan tanaman diekspresikan 
melalui proses biokimia dan fisiologis. Perbedaan susunan genetik merupakan salah satu faktor penyebab keragaman penampilan tanaman.

\section{Jumlah Daun (helai)}

Rata-rata jumlah daun bibit kakao pada umur 20, 35, 50 dan 65 HST akibat perlakuan jenis tanah marginal disajikan pada Tabel 3.

Tabel 3. Rata-rata Jumlah Daun Bibit Kakao akibat Perlakuan Jenis Tanah Marginal

\begin{tabular}{ccccc}
\hline \multirow{2}{*}{ Perlakuan } & \multicolumn{4}{c}{ Jumlah Daun (helai) } \\
\cline { 2 - 5 } & $20 \mathrm{HST}$ & $35 \mathrm{HST}$ & $50 \mathrm{HST}$ & 65 HST \\
\hline $\mathrm{T}_{1}$ & 7,75 & $11,29 \mathrm{~b}$ & $17,46 \mathrm{~b}$ & $25,58 \mathrm{~b}$ \\
$\mathrm{~T}_{2}$ & 7,08 & $9,75 \mathrm{a}$ & $14,92 \mathrm{a}$ & $22,17 \mathrm{a}$ \\
$\mathrm{T}_{3}$ & 7,67 & $10,29 \mathrm{ab}$ & $14,96 \mathrm{a}$ & $22,83 \mathrm{a}$ \\
$\mathrm{T}_{4}$ & 7,42 & $10,13 \mathrm{ab}$ & $14,67 \mathrm{a}$ & $22,58 \mathrm{a}$ \\
\hline BNJ $_{0,05}$ & th & 1,16 & 2,32 & 2,62 \\
\hline
\end{tabular}

Keterangan: Angka yang diikuti oleh huruf yang sama pada kolom yang sama berbeda tidak nyata pada uji $\mathrm{BNJ}_{0,05}$

Tabel 3 menunjukkan bahwa jumlah daun bibit kakao umur 35, 50 dan 65 HST tertinggi dijumpai pada perlakuan $\mathrm{T}_{1}$. Pada umur 35 HST perlakuan $\mathrm{T}_{1}$ secara uji $\mathrm{BNJ}_{0,05}$ berbeda nyata dengan perlakuaan $T_{2}$, namun berbeda tidak nyata dengan perlakuan $T_{3}$ dan $T_{4}$. Pada umur 50 dan 65 HST perlakuan $\mathrm{T}_{1}$ secara uji $\mathrm{BNJ}_{0,05}$ berbeda nyata dengan perlakuan $\mathrm{T}_{2}, \mathrm{~T}_{3}$ dan $\mathrm{T}_{4}$. Hal ini disebabkan tanah top soil banyak mengandung bahan organik dan mempunyai kemampuan menyerap dan menyimpan air dengan baik dibandingkan dengan tanah marginal, sehingga dapat meningkatkan pertumbuhan bibit kakao seperti pembentukan daun.

Hal tersebut sesuai dengan pendapat Hidayat $d k k$., (2007) bahwa tanah top soil mengandung bahan organik, berwarna gelap dan subur. Tanah top soil memiliki kemampuan menyerap dan menyimpan air dengan baik. Selanjutnya Munawar (2013) menyatakan bahwa peran dan fungsi bahan organik tanah dapat meningkatkan kesuburan dan nutrisi tanaman. Bahan organik yang terakumulasi di dalam tanah merupakan penyimpan dan pemasok hara-hara esensial tanaman, karena sebagian besar bahan organik berasal dari sisa-sisa tanaman sehingga mengandung semua hara yang dibutuhkan tanaman. Bahan organik mampu memperbaiki sifat-sifat tanah yang dapat menjaga ketersediaan unsur hara di dalam tanah dan membuat kondisi tanah cocok untuk pertumbuhan tanaman.

\section{Panjang Daun (cm)}

Rata-rata panjang daun bibit kakao pada umur 20, 35, 50 dan 65 HST akibat perlakuan jenis tanah marginal disajikan pada Tabel 4.

Tabel 4. Rata-rata Panjang Daun Bibit Kakao akibat Perlakuan Jenis Tanah Marginal

\begin{tabular}{ccccc}
\hline \multirow{2}{*}{ Perlakuan } & \multicolumn{4}{c}{ Panjang Daun $(\mathrm{cm})$} \\
\cline { 2 - 5 } & $20 \mathrm{HST}$ & $35 \mathrm{HST}$ & $50 \mathrm{HST}$ & 65 HST \\
\hline $\mathrm{T}_{1}$ & 11,07 & $14,50 \mathrm{~b}$ & $17,06 \mathrm{~b}$ & $20,15 \mathrm{~b}$ \\
$\mathrm{~T}_{2}$ & 10,38 & $12,77 \mathrm{a}$ & $14,69 \mathrm{a}$ & $17,52 \mathrm{a}$ \\
$\mathrm{T}_{3}$ & 10,12 & $13,40 \mathrm{ab}$ & $15,44 \mathrm{a}$ & $18,29 \mathrm{a}$ \\
$\mathrm{T}_{4}$ & 9,96 & $13,21 \mathrm{ab}$ & $15,13 \mathrm{a}$ & $18,48 \mathrm{a}$ \\
\hline BNJ $_{0,05}$ & $\mathrm{tn}$ & 1,29 & 1,37 & 1,65 \\
\hline
\end{tabular}

Keterangan: Angka yang diikuti oleh huruf yang sama pada kolom yang sama berbeda tidak nyata pada uji $\mathrm{BNJ}_{0,05}$

Tabel 4 menunjukkan bahwa panjang daun bibit kakao umur 35, 50 dan 65 HST tertinggi dijumpai pada perlakuan $\mathrm{T}_{1}$. Pada umur $35 \mathrm{HST}$ perlakuan $\mathrm{T}_{1}$ secara uji $\mathrm{BNJ}_{0,05}$ berbeda nyata dengan 
perlakuaan $T_{2}$, namun berbeda tidak nyata dengan perlakuan $T_{3}$ dan $T_{4}$. Pada umur 50 dan 65 HST perlakuan $T_{1}$ secara uji $\mathrm{BNJ}_{0,05}$ berbeda nyata dengan perlakuan $\mathrm{T}_{2}, \mathrm{~T}_{3}$ dan $\mathrm{T}_{4}$. Hal ini disebabkan media tanah top soil mengandung bahan organik dan unsur hara yang dapat dimanfaatkan bibit kakao untuk pertumbuhan vegetatif seperti peningkatan panjang daun. Hal tersebut sesuai dengan pendapat Ginting $d k k$., (2015) bahwa ketersediaan unsur hara dalam tanah tidak terlepas dengan proses mineralisasi yang merupakan tahap akhir dari proses perombakan bahan organik. Dalam proses mineralisasi akan dilepas mineral-mineral hara tanaman dengan lengkap (N, P, K, Ca, Mg dan S, serta hara mikro).

\section{Bobot Brangkasan Basah Bibit dan Bobot Basah Akar (g)}

Rata-rata bobot brangkasan basah bibit dan bobot basah akar bibit kakao akibat perlakuan jenis tanah marginal disajikan pada Tabel 5.

Tabel 5. Rata-rata Bobot Brangkasan Basah Bibit dan Bobot Basah Akar Bibit Kakao akibat Perlakuan Jenis Tanah Marginal

\begin{tabular}{ccc}
\hline Perlakuan & Bobot Brangkasan Basah Bibit $(\mathrm{g})$ & Bobot Basah Akar $(\mathrm{g})$ \\
\hline $\mathrm{T}_{1}$ & $28,38 \mathrm{~b}$ & $7,63 \mathrm{~b}$ \\
$\mathrm{~T}_{2}$ & $22,63 \mathrm{a}$ & $5,75 \mathrm{a}$ \\
$\mathrm{T}_{3}$ & $23,63 \mathrm{a}$ & $5,88 \mathrm{a}$ \\
$\mathrm{T}_{4}$ & $24,13 \mathrm{a}$ & $6,13 \mathrm{a}$ \\
\hline $\mathrm{BNJ}_{0,05}$ & 3,80 & 1,45 \\
\hline
\end{tabular}

Keterangan : Angka yang diikuti oleh huruf yang sama pada kolom yang sama berbeda tidak nyata pada uji BNJ $_{0,05}$

Tabel 5 menunjukkan bahwa bobot brangkasan basah bibit dan bobot basah kakao tertinggi dijumpai pada perlakuan $\mathrm{T}_{1}$ yang secara uji $\mathrm{BNJ}_{0,05}$ berbeda nyata dengan perlakuaan yang lain. Hasil ini sejalan dengan pertumbuhan morfologi bibit (tinggi bibit, diameter bibit, jumlah daun dan panjang daun) bibit kakao, dimana pertumbuhan morfologi bibit pada media tanah top soil lebih baik dibandingkan dengan media marginal sehigga bobot basah bibit kakao yang didapatkan pada media top soil lebih tinggi. Hal tersebut sejalan dengan pendapat Anjarsary dkk., (2007) menyatakan bahwa bobot basah bibit merupakan salah satu indikator pertumbuhan tanaman. Nilai bobot basah bibit yang tinggi menunjukkan terjadinya peningkatan proses fotosintesis karena unsur hara yang diperlukan cukup tersedia. Hal tersebut berhubungan dengan hasil fotosintat yang ditranslokasikan ke seluruh organ tanaman untuk pertumbuhan tanaman, sehingga memberikan pengaruh yang nyata pada bobot basah bibit.

Media tanam top soil mengandung bahan organik yang bermanfaat dalam memperbaiki sifat fisik dan kimia tanah. Tanah top soil memiliki struktur tanah yang gembur, pada keadaan tersebut dapat meningkatkan pertumbuhan akar bibit kakao sehingga menghasilkan bobot basah akar yang lebih tinggi. Hal tersebut sesuai dengan pendapat Prasetyo dan Suriadikarta, (2006) yang menyatakan bahwa bahan organik yang terdapat pada tanah top soil selain dapat meningkatkan sifat kimia tanah juga mempunyai peran penting dalam memperbaiki sifat fisik tanah. Bahan organik dapat meningkatkan agregasi tanah, memperbaiki aerasi dan perkolasi, serta membuat struktur tanah menjadi lebih remah.

\section{Respon Pertumbuhan Bibit Kakao akibat Dosis Mikoriza}

\section{Tinggi Bibit (cm)}

Rata-rata tinggi bibit kakao pada umur 20, 35, 50 dan 65 HST akibat perlakuan dosis mikoriza disajikan pada Tabel 6 . 
Tabel 6. Rata-rata Tinggi Bibit Kakao akibat Perlakuan Dosis Mikoriza

\begin{tabular}{ccccc}
\hline \multirow{2}{*}{ Perlakuan } & \multicolumn{4}{c}{ Tinggi Bibit $(\mathrm{cm})$} \\
\cline { 2 - 5 } & $20 \mathrm{HST}$ & $35 \mathrm{HST}$ & $50 \mathrm{HST}$ & $65 \mathrm{HST}$ \\
\hline $\mathrm{M}_{0}$ & 10,13 & $13,31 \mathrm{a}$ & $17,40 \mathrm{a}$ & $23,75 \mathrm{a}$ \\
$\mathrm{M}_{1}$ & 10,65 & $14,17 \mathrm{a}$ & $17,65 \mathrm{a}$ & $24,88 \mathrm{a}$ \\
$\mathrm{M}_{2}$ & 11,13 & $14,36 \mathrm{ab}$ & $18,40 \mathrm{ab}$ & $26,27 \mathrm{ab}$ \\
$\mathrm{M}_{3}$ & 11,19 & $15,46 \mathrm{~b}$ & $20,00 \mathrm{~b}$ & $28,23 \mathrm{~b}$ \\
\hline $\mathrm{BNJ}_{0,05}$ & $\mathrm{tn}$ & 1,26 & 1,76 & 2,25 \\
\hline
\end{tabular}

Keterangan : Angka yang diikuti oleh huruf yang sama pada kolom yang sama berbeda tidak nyata pada uji $\mathrm{BNJ}_{0,05}$

Tabel 6 menunjukkan bahwa tinggi bibit kakao umur 20, 35, 50 dan 65 HST tertinggi dijumpai pada perlakuan $\mathrm{M}_{3}$ (15 g/polybag) yang secara uji $\mathrm{BNJ}_{0,05}$ berbeda nyata dengan perlakuaan $\mathrm{M}_{0}$ (0 g/polybag) dan $\mathrm{M}_{1}$ (5 g/polybag), namun berbeda tidak nyata dengan perlakuan $\mathrm{M}_{2}$ (10 g/polybag). Hal ini diduga pada aplikasi mikoriza 10-15 g/polybag dapat meningkatkan kemampuan mikoriza dalam membentuk simbiosis dengan akar bibit kakao, sehingga dapat meningkatkan serapan unsur hara dan air, serta meningkatkan hormon zat pengatur tumbuh yang dibutuhkan bibit kakao untuk pertumbuhan tinggi bibit.

Hal tersebut sesuai dengan pendapat Nurhayati (2012) yang menyatakan bahwa mikoriza mampu membantu meningkatkan serapan hara dan air serta mampu meningkatkan produksi hormon pertumbuhan dan zat pengatur tumbuh lainnya (seperti auxin, sitokinin, giberelin dan vitamin) terhadap tanaman inangnya. Selanjutnya hasil yang didapatkan sejalan dengan hasil penelitian Nasrullah $d k k$., (2015) bahwa pemberian mikoriza dengan dosis $10 \mathrm{~g} / \mathrm{tanaman}$ dan $15 \mathrm{~g} / \mathrm{tanaman}$ mampu mendukung pertumbuhan tinggi bibit kakao.

\section{Diameter Pangkal Batang (mm)}

Rata-rata diameter pangkal batang bibit kakao pada umur 20, 35, 50 dan 65 HST akibat perlakuan dosis mikoriza disajikan pada Tabel 7.

Tabel 7. Rata-rata Diameter Pangkal Batang Bibit Kakao akibat Perlakuan Dosis Mikoriza

\begin{tabular}{ccccc}
\hline \multirow{2}{*}{ Perlakuan } & \multicolumn{4}{c}{ Diameter Pangkal Batang (mm) } \\
\cline { 2 - 5 } & $20 \mathrm{HST}$ & $35 \mathrm{HST}$ & $50 \mathrm{HST}$ & $65 \mathrm{HST}$ \\
\hline $\mathrm{M}_{0}$ & 2,71 & 3,90 & 5,05 & 6,87 \\
$\mathrm{M}_{1}$ & 2,89 & 3,94 & 5,20 & 7,33 \\
$\mathrm{M}_{2}$ & 2,93 & 4,20 & 5,31 & 7,30 \\
$\mathrm{M}_{3}$ & 3,03 & 4,47 & 5,62 & 7,60 \\
\hline
\end{tabular}

Tabel 7 menunjukan bahwa pertumbuhan bibit kakao akibat perlakuan dosis mikoriza menunjukkan respon yang tidak nyata padadiameter pangkal batang umur 20, 35, 50 dan 65 HST. Hal ini diduga diameter pangkal batang bibit kakao lebih dipengaruhi oleh faktor internal dan eksternal dari pada faktor yang diujikan sehingga respon yang ditimbulkan terhadap pertumbuhan diameter pangkal batang tidak terlihat. Hal ini sesuai dengan pendapat Diah (2017) secara umum faktor-faktor yang mempengaruhi pertumbuhan dan perkembangan tumbuhan terdiri dari faktor eksternal dan faktor internal. Faktor-faktor eksternal antara lain tanah, kelembapan, udara, suhu, cahaya dan air. Faktor-faktor internal dapat mencakup gen, kandungan klorofil serta struktur morfologi dan anatomi organ tumbuhan.

\section{Jumlah Daun (helai)}

Rata-rata jumlah daun bibit kakao pada umur 20, 35, 50 dan 65 HST akibat perlakuan dosis mikoriza disajikan pada Tabel 8. 
Tabel 8. Rata-rata Jumlah Daun Bibit Kakao akibat Perlakuan Dosis Mikoriza

\begin{tabular}{ccccc}
\hline \multirow{2}{*}{ Perlakuan } & \multicolumn{4}{c}{ Jumlah Daun (helai) } \\
\cline { 2 - 5 } & $20 \mathrm{HST}$ & $35 \mathrm{HST}$ & $50 \mathrm{HST}$ & 65 HST \\
\hline $\mathrm{M}_{0}$ & 7,17 & $9,46 \mathrm{a}$ & $14,25 \mathrm{a}$ & $20,63 \mathrm{a}$ \\
$\mathrm{M}_{1}$ & 7,46 & $9,88 \mathrm{ab}$ & $15,00 \mathrm{ab}$ & $22,92 \mathrm{ab}$ \\
$\mathrm{M}_{2}$ & 7,42 & $10,71 \mathrm{bc}$ & $16,13 \mathrm{ab}$ & $24,29 \mathrm{~b}$ \\
$\mathrm{M}_{3}$ & 7,88 & $11,42 \mathrm{c}$ & $16,63 \mathrm{~b}$ & $25,33 \mathrm{~b}$ \\
\hline BNJ $_{0,05}$ & $\mathrm{tn}$ & 1,16 & 2,32 & 2,62 \\
\hline
\end{tabular}

Keterangan: Angka yang diikuti oleh huruf yang sama pada kolom yang sama berbeda tidak nyata pada uji $\mathrm{BNJ}_{0,05}$

Tabel 8 menunjukkan bahwa jumlah daun bibit kakao umur 35, 50 dan 65 HST tertinggi dijumpai pada perlakuan $\mathrm{M}_{3}$. Pada umur 35 HST perlakuan $\mathrm{M}_{3}$ secara uji $\mathrm{BNJ}_{0,05}$ berbeda nyata dengan perlakuaan $\mathrm{M}_{0}$ dan $\mathrm{M}_{1}$, namun berbeda tidak nyata dengan perlakuan $\mathrm{M}_{2}$. Pada umur 50 dan 65 HST perlakuan $\mathrm{M}_{3}$ secara uji $\mathrm{BNJ}_{0,05}$ berbeda nyata dengan perlakuan $\mathrm{M}_{0}$, namun berbeda tidak nyata dengan perlakuan $\mathrm{M}_{1}$. dan $\mathrm{M}_{2}$. Hal ini disebabkan pada aplikasi mikoriza $15 \mathrm{~g} /$ polybag dapat meningkatkan efesiensi pemupukan dan meningkatkan serapan hara yang dibutuhkan tanaman untuk proses metabolisme, sehingga dapat meningkatkan pertumbuhan bibit kakao seperti peningkatan jumlah daun. Hal tersebut sesuai dengan pendapat Saputra $d k k$., (2016) yang menyatakan bahwa aplikasi mikoriza arbuskula mampu meningkatkan serapan hara, baik hara makro maupun hara mikro, sehingga penggunaan mikoriza arbuskula dapat dijadikan sebagai alat biologis untuk mengurangi dan mengefisiensi penggunaan pupuk buatan.

\section{Panjang Daun (cm)}

Rata-rata panjang daun bibit kakao pada umur 20, 35, 50 dan 65 HST akibat perlakuan dosis mikoriza disajikan pada Tabel 9.

Tabel 9. Rata-rata Panjang Daun Bibit Kakao akibat Perlakuan Dosis Mikoriza

\begin{tabular}{ccccc}
\hline \multirow{2}{*}{ Perlakuan } & \multicolumn{4}{c}{ Panjang Daun $(\mathrm{cm})$} \\
\cline { 2 - 5 } & $20 \mathrm{HST}$ & $35 \mathrm{HST}$ & $50 \mathrm{HST}$ & 65 HST \\
\hline $\mathrm{M}_{0}$ & 9,76 & $12,40 \mathrm{a}$ & $14,46 \mathrm{a}$ & $17,46 \mathrm{a}$ \\
$\mathrm{M}_{1}$ & 10,23 & $13,23 \mathrm{ab}$ & $15,56 \mathrm{ab}$ & $18,13 \mathrm{a}$ \\
$\mathrm{M}_{2}$ & 10,46 & $13,85 \mathrm{ab}$ & $15,75 \mathrm{ab}$ & $18,94 \mathrm{ab}$ \\
$\mathrm{M}_{3}$ & 11,08 & $14,40 \mathrm{~b}$ & $16,54 \mathrm{~b}$ & $19,92 \mathrm{~b}$ \\
\hline $\mathrm{BNJ}_{0,05}$ & $\mathrm{tn}$ & 1,29 & 1,37 & 1,65 \\
\hline
\end{tabular}

Keterangan : Angka yang diikuti oleh huruf yang sama pada kolom yang sama berbeda tidak nyata pada uji $\mathrm{BNJ}_{0,05}$

Tabel 9 menunjukkan bahwa panjang daun bibit kakao umur 35, 50 dan 65 HST tertinggi dijumpai pada perlakuan $\mathrm{M}_{3}$. Pada umur 35 dan 50 HST perlakuan $\mathrm{M}_{3}$ secara uji $\mathrm{BNJ}_{0,05}$ berbeda nyata dengan perlakuaan $M_{0}$, namun berbeda tidak nyata dengan perlakuan $M_{1}$ dan $M_{2}$. Pada umur 65 HST perlakuan $\mathrm{M}_{3}$ secara uji $\mathrm{BNJ}_{0,05}$ berbeda nyata dengan perlakuan $\mathrm{M}_{0}$ dan $\mathrm{M}_{1}$, namun berbeda tidak nyata dengan perlakuan $\mathrm{M}_{2}$. Hal ini disebabkan aplikasi mikoriza dengan dosis $15 \mathrm{~g} /$ polybag dapat meningkatkan penyerapan unsur hara oleh bibit, sehingga dapat meningkatkan pertumbuhan panjang daun bibit kakao. Hal tersebut sesuai dengan pendapat Noertjahyani, (2012) bahwa kehadiran mikoriza arbuskular pada akar tanaman dapat meningkatkan penyerapan unsur hara (khususnya hara immobile) dan air, memacu pertumbuhan akar tanaman dari hormon tumbuh yang dihasilkan, melindungi tanaman dari keracunan logam berat, dan meningkatkan ketahanan tanaman dari patogen. Dengan adanya asosiasi ini, mengakibatkan pertumbuhan tanaman meningkat. 


\section{Bobot Brangkasan Basah Bibit dan Bobot Basah Akar (g)}

Rata-rata bobot brangkasan basah bibit dan bobot basah akar bibit kakao akibat perlakuan dosis mikoriza disajikan pada Tabel 10.

Tabel 10. Rata-rata Bobot Brangkasan Basah Bibit dan Bobot Basah Akar Bibit Kakao akibat Perlakuan Dosis Mikoriza

\begin{tabular}{ccc}
\hline Perlakuan & Bobot Brangkasan Basah Bibit $(\mathrm{g})$ & Bobot Basah Akar $(\mathrm{g})$ \\
\hline $\mathrm{M}_{0}$ & $21,25 \mathrm{a}$ & $4,75 \mathrm{a}$ \\
$\mathrm{M}_{1}$ & $24,25 \mathrm{ab}$ & $6,25 \mathrm{ab}$ \\
$\mathrm{M}_{2}$ & $25,50 \mathrm{~b}$ & $6,75 \mathrm{~b}$ \\
$\mathrm{M}_{3}$ & $27,75 \mathrm{~b}$ & $7,63 \mathrm{~b}$ \\
\hline $\mathrm{BNJ}_{0,05}$ & 3,80 & 1,45 \\
\hline Keterangan : Angka yang diikuti oleh huruf yang sama pada kolom yang sama berbeda tidak nyata pada uji \\
\end{tabular}

Tabel 10 menunjukkan bahwa bobot brangkasan basah dan bobot basah akar bibit kakao tertinggi dijumpai pada perlakuan $\mathrm{M}_{3}$ yang secara uji $\mathrm{BNJ}_{0,05}$ berbeda nyata dengan perlakuan $\mathrm{M}_{0}$, namun berbeda tidak nyata dengan perlakuan $\mathrm{M}_{1}$ dan $\mathrm{M}_{2}$. Hal ini diduga pemberian mikoriza dengan dosis $15 \mathrm{~g} /$ polibag dapat meningkatkan penyerapan unsur hara seperti unsur hara $\mathrm{P}$ oleh akar tanaman untuk pertumbuhan bibit kakao, sehingga dapat meningkatkan bobot brangkasan basah bibit kakao, selanjutnya unsur hara $\mathrm{P}$ sangat dibutuhkan untuk pembentukan dan perkembangan akar sehingga dapat meningkatkan bobot basar akar bibit kakao.Hal tersebut sesuai dengan pendapat Rusdi $d k k$., (2011) menyatakan bahwa aplikasi mikoriza dapat meningkatkan daya tumbuh tanaman. Selain itu mikoriza juga berperan dalam memacu pertumbuhan tanaman. Meningkatkan efisiensi pemupukan dan serapan hara melalui asosiasi simbiotik antara akar tanaman. Hal tersebut sesuai dengan pendapat Nurhayati (2012) yang menyatakan bahwa peningkatan jumlah unsur $\mathrm{P}$ tersedia dalam tanah dikarenakan $\mathrm{P}$ terbebas dari fiksasi $\mathrm{Al}$ maupun ikatan $\mathrm{Ca}-\mathrm{P}$, selanjutnya mikoriza juga akan membentuk hifa eksternal yang memiliki spora dimana hifa eksternal tersebut berfungsi menyerap unsur hara $\mathrm{P}$ yang dirubah menjadi senyawa polifosfat (enzim fosfatase) dan dipindahkan ke hifa internal dan arbuskula untuk diubah menjadi fosfat anorganik yang kemudian dilepaskan ke dalam jaringan tanaman inang. Menurut Sutedjo (2010) unsur fosfat berperan dalam membantu pembentukan protein dan mineral bagi tanaman dan dapat mempercepat pertumbuhan akar.

\section{Respon Pertumbuhan Bibit Kakao akibat Jenis Tanah Marginal}

Rata-rata jumlah daun bibit kakao akibat respon interaksi antara jenis tanah marginal dan dosis mikoriza disajikan pada Tabel 11. Interaksi antara jenis tanah marginal dan dosis mikoriza, menunjukkan respon yang nyata terhadap parameter jumlah jumlah daun bibit kakao umur 35 HST, sedangkan untuk parameter yang lain menunjukkan respon yang tidak nyata. Tabel 11 menunjukkan jumlah daun bibit kakao pada umur 35 HST tertinggi dijumpai pada perlakuan $\mathrm{T}_{1} \mathrm{M}_{3}$ (jenis tanah top soil dan dosis mikoriza $15 \mathrm{~g} /$ polybag) yang secara uji $\mathrm{BNJ}_{0,05}$ berbeda nyata dengan perlakuan $\mathrm{T}_{1} \mathrm{M}_{0}$, $\mathrm{T}_{1} \mathrm{M}_{1}, \mathrm{~T}_{1} \mathrm{M}_{2}, \mathrm{~T}_{2} \mathrm{M}_{0}, \mathrm{~T}_{2} \mathrm{M}_{2}, \mathrm{~T}_{2} \mathrm{M}_{3}, \mathrm{~T}_{3} \mathrm{M}_{0}, \mathrm{~T}_{3} \mathrm{M}_{1}, \mathrm{~T}_{3} \mathrm{M}_{3}, \mathrm{~T}_{4} \mathrm{M}_{0}, \mathrm{~T}_{4} \mathrm{M}_{1}$ dan $\mathrm{T}_{4} \mathrm{M}_{2}$, namun berbeda tidak nyata dengan perlakuan $\mathrm{T}_{3} \mathrm{M}_{2}$ dan $\mathrm{T}_{4} \mathrm{M}_{3}$. Kombinasi perlakuan media tanam tanah top soil dan pemberian dosis mikoriza $15 \mathrm{~g} /$ polybag $\left(\mathrm{T}_{1} \mathrm{M}_{3}\right)$ merupakan kombinasi perlakuan yang terbaik. Hal tersebut karena inokulasi cendawan mikoriza $15 \mathrm{~g} /$ polybag pada tanah top soil sebagai media tanam tanaman kakao dapat meningkatkan penyerapan hara dan air oleh tanaman dengan adanya asosiasi akar dengan cendawan mikoriza, sehingga proses fotosintesis dapat berjalan dengan baik dan dapat meningkatkan jumlah daun bibit kakao. 
Tabel 11. Rata-rata Jumlah Daun Bibit Kakao akibat Interaksi Jenis Tanah Marginal dan Dosis Mikoriza.

\begin{tabular}{cc}
\hline Perlakuan & Jumlah Daun (helai) \\
\hline $\mathrm{T}_{1} \mathrm{M}_{0}$ & $9,67 \mathrm{abc}$ \\
$\mathrm{T}_{1} \mathrm{M}_{1}$ & $10,50 \mathrm{abc}$ \\
$\mathrm{T}_{1} \mathrm{M}_{2}$ & $11,33 \mathrm{bc}$ \\
$\mathrm{T}_{1} \mathrm{M}_{3}$ & $13,67 \mathrm{~d}$ \\
$\mathrm{~T}_{2} \mathrm{M}_{0}$ & $9,00 \mathrm{a}$ \\
$\mathrm{T}_{2} \mathrm{M}_{1}$ & $10,00 \mathrm{abc}$ \\
$\mathrm{T}_{2} \mathrm{M}_{2}$ & $9,50 \mathrm{ab}$ \\
$\mathrm{T}_{2} \mathrm{M}_{3}$ & $10,50 \mathrm{abc}$ \\
$\mathrm{T}_{3} \mathrm{M}_{0}$ & $9,67 \mathrm{abc}$ \\
$\mathrm{T}_{3} \mathrm{M}_{1}$ & $10,00 \mathrm{abc}$ \\
$\mathrm{T}_{3} \mathrm{M}_{2}$ & $11,67 \mathrm{~cd}$ \\
$\mathrm{~T}_{3} \mathrm{M}_{3}$ & $9,83 \mathrm{abc}$ \\
$\mathrm{T}_{4} \mathrm{M}_{0}$ & $9,50 \mathrm{ab}$ \\
$\mathrm{T}_{4} \mathrm{M}_{1}$ & $9,00 \mathrm{a}$ \\
$\mathrm{T}_{4} \mathrm{M}_{2}$ & $10,33 \mathrm{abc}$ \\
$\mathrm{T}_{4} \mathrm{M}_{3}$ & $11,67 \mathrm{~cd}$ \\
\hline $\mathrm{BNJ}_{0,05}$ & 2,08 \\
\hline
\end{tabular}

Keterangan : Angka yang diikuti oleh huruf yang sama berbeda tidak nyata pada uji $\mathrm{BNT}_{0,05}$.

Hal tersebut sesuai dengan pendapat Ginting $d k k$., (2015) yang menyatakan bahwa bahan organik dalam tanah dapat meningkatkan agregasi tanah, memperbaiki aerasi dan perkolasi, serta membuat struktur tanah menjadi lebih remah. Menurut Hanafiah $d k k$., (2009) tanah dengan kandungan bahan organik rendah tidak dapat memberikan kondisi lingkungan yang sesuai untuk aktivitas mikroorganisme.

\section{Kesimpulan}

\section{KESIMPULAN DAN SARAN}

1. Pertumbuhan bibit kakao akibat perlakuan jenis tanah marginal menunjukkan respon yang sangat nyata terhadap tinggi bibit umur (50 dan 65 HST), jumlah daun umur 65 HST, panjang daun umur (50 dan 65 HST), bobot brangkasan basah bibit, bobot basah akar, respon nyata terhadap tinggi bibit umur (20 dan 35 HST), jumlah daun umur (35 dan 50 HST) dan panjang daun umur 35 HST, sedangkan parameter lainnya menunjukkan respon yang tidak nyata. Perlakuan jenis tanah marginal terbaik adalah tanah top soil (kontrol) $\left(\mathrm{T}_{1}\right)$.

2. Pertumbuhan bibit kakao akibat perlakuan dosis mikoriza menunjukkan respon yang sangat nyata terhadap tinggi bibit umur (35, 50 dan 65 HST), jumlah daun umur (35 dan 65 HST), panjang daun umur (35, 50 dan 65 HST), bobot brangkasan basah bibit, bobot basah akar, respon nyata terhadap jumlah daun umur 50 HST, sedangkan parameter lainnya menunjukkan respon yang tidak nyata. Perlakuan dosis mikoriza terbaik adalah $15 \mathrm{~g} /$ polybag $\left(\mathrm{M}_{3}\right)$.

3. Interaksi antara jenis tanah marginal dan dosis mikoriza memberikan respon yang nyata terhadap parameter jumlah daun bibit kakao umur 35 HST. Kombinasi perlakuan terbaik yaitu jenis tanah marginal tanah top soil dan dosis mikoriza $15 \mathrm{~g} /$ polybag $\left(\mathrm{T}_{1} \mathrm{M}_{3}\right)$ yang dilakukan secara bersamaan.

\section{Saran}

1. Berdasarkan hasil penelitian, disarankan untuk mendapatkan pertumbuhan bibit kakao yang baik, agar menggunakan tanah top soil dengan pemberian mikoriza $15 \mathrm{~g} /$ polybag. 
2. Mengingat aspek penelitian ini sangat terbatas maka disarankan kepada pihak lain untuk melaksanakan penelitian dengan menggunakan jenis tanah marginal yang lain dengan pemberian dosis mikoriza yang lebih tinggi.

\section{DAFTAR PUSTAKA}

Anjarsary IRD, Rosniawati S, Ariyanti M. 2007. Pengaruh Kombinasi Pupuk P dan Kompos terhadap Pertumbuhan Tanaman Teh (Camellia sinensis (L.) O. Kuntze) belum menghasilkan Klon Gambung 7. Laporan Penelitian Peneliti Muda UNPAD. PPTK Gambung.

[BPS] Badan Pusat Statistik Indonesia. 2017. Produksi Kakao Menurut Provinsi di Indonesia, 2013 2017. Badan Pusat Statistik. Jakarta.

Diah A. 2017. Pengaruh Faktor Lingkungan terhadap Perubahan Struktur Anatomi Daun. Prosiding Seminar Nasional Jurusan Pendidikan Biologi. Fakultas Matematika dan Ilmu Pengetahuan Alam (MIPA). Universitas Negeri Yogyakarta

Ginting KR, Gunawan T, Sukemi IS. 2015. Pertumbuhan Bibit Kakao (Theobroma cacao L.) yang Ditanampada Beberapa Medium Tumbuh dengan Pemberian Pupuk Organik Cair. Jurnal Jom Faperta. 2 (1) : 1-10.

Hanafiah AS, Sabrina T, Guchi H. 2009. Biologi dan Ekologi Tanah. USU Press. Medan.

Hidayat TC, Simangsunsong G, Eka LI, Harahap Y. 2007. Pemanfaatan Berbagai Limbah Pertanian untuk Pembenah Media Tanam Bibit Kelapa Sawit. Jurnal Penelitian Kelapa Sawit. 15 (2): 185-193.

Idhan A, Nursjamsi. 2016. Aplikasi Mikoriza dan Pupuk Organik terhadapPertumbuhan Tanaman Kakao (Theobroma cacao, L.) di Kabupaten Gowa. Jurnal Perspektif. 1 (1) : 1-11.

Kusnoto, Kusumodidjo. 1995. Dampak Penambangan dan Reklamasi. Pusat Pengembangan Tenaga Pertambangan. Bandung.

Lukito AM, Mulyono, Tetty Y, Hadi I, Noviandi R. 2010. Budidaya Kakao. Agro Media. Jakarta.

Munawar A. 2011. Kesuburan Tanah dan Nutrisi Tanaman. Institut Pertanian Bogor Press. Bogor.

Nasrullah, Nurhayati, Marliah A. 2015. Pengaruh Dosis Pupuk NPK (16:16:16) dan Mikoriza terhadap Pertumbuhan Bibit Kakao (Theobroma cacao L.) pada Media Tumbuh Subsoil. Jurnal Agrium. 12 (2) : 56-64.

Nurhayati. 2012. Pengaruh Berbagai JenisTanaman Inang dan Beberapa Jenis Sumber Inokulum terhadap Infektivitas dan Efektivitas Mikoriza. Jurnal Agrista. 16 (2): 80-86.

Noertjahyani. 2012. Respon PertumbuhanKolonisasi Mikoriza dan Hasil TanamanKedelai sebagai Akibat dari Takaran Kompos dan Mikoriza Arbuskular. Skripsi. Program Studi Agrotekonologi Fakultas Pertanian Universitas Winaya Mukti.

Nyakpa MY, Hakim N, Lubis AM., Nugroho SG, Diha MA, Hong GB, Bailey HH. 2002. DasarDasar Ilmu Tanah. Universitas Lampung. Lampung.

Prasetyo BH, Suriadikarta DA. 2006. Karakteristik, Potensi, Dan Teknologi Pengelolaan Tanah Ultisol untuk Pengembangan Pertanian Lahan Kering di Indonesia. Laporan Penelitian. Litbang Pertanian. 2 (25): 1-39.

Rusdi, Suharsono S, Mustikarini SD, 2011. Pengaruh Pemberian Mikoriza Terhadap Pertumbuhan Nenas Bogor (Lokal Bangka) Di PMK Bangka. Jurnal Pertanian dan Lingkungan. 3 (1) : 143.

Saputra D, Ashabul A, Erida N. 2016. Pengaruh Dosis Jamur Mikoriza Arbuskula dan Pupuk Rock Fosfat terhadap Pertumbuhan Bibit Kakao (Theobroma cacao, L). Jurnal Penelitian Universitas Jambi Seri Sains. 18 (2): 20-30.

Sitompul SM, Guritno B. 1995. Analisis Pertumbuhan Tanaman. Gadjah Mada University Press. Yoyakarta.

Sutedjo MM. 2010. Pupuk dan Cara Pemupukan. Rineka Cipta. Jakarta.

Yuwono NW. 2009. Membangun Kesuburan Tanah di Lahan Marginal. Jurnal Ilmu Tanah dan Lingkungan. 9 (2) : 137-141. 